\title{
Constructing Assesment Model for Pancasila Education Design
}

\author{
Airin Yustikarini Saleh* and Eko Aditiya Meinarno \\ Faculty of Psychology \\ Universitas Indonesia \\ Depok, Indonesia \\ *airys.psi@gmail.com
}

\begin{abstract}
The making of this assessment model is a continuation of the teaching design of Pancasila Education proposed by Meinarno and Saleh (2017). The teaching design of the Pancasila Education course uses problem-based learning methodology. The method is chosen to develop undergraduate students' analytical skills in mastering the knowledge needed to understand the problem. This teaching design can make undergraduate students active in building their knowledge, following the expected competencies (Meinarno \& Saleh, 2017). Based on this, it is necessary to design an assessment model to measure the achievement of the learning objectives in the design. The method used in this research is literature study. The results achieved are to obtain an assessment model of the Pancasila Education process, such as the design of the discussion form, the design of the student presentation evaluation, the design of formative and summative exams. This result will be a consideration for the implementation of the teaching process of Pancasila Education at universities in Indonesia.
\end{abstract}

Keywords- assessment; pancasila education; problem-based learning; undergraduate students

\section{INTRODUCTION}

Education of Pancasila in college has been implemented for many years. In practice, the approach most used in all education level is teacher-centered, which uses many lecture methods. In the summary from regulation by Ministry for Research and Higher Education (Permenristekdikti) No. 44/2015 about National Standard of Higher Education (SNPT Dikti) [1] emphasizes that Pancasila Education, especially in universities, has a goal to develop strong and positive characters in students based on values of Pancasila, named as sila. Based on this goal, Meinarno and Saleh in previous study proposed a teaching design that is expected to develop the character based on Pancasila values [2]. In the design of the teaching design, the purpose is to implement more about the active learning approach in teaching Pancasila Education. The learning method based on the approach used in Pancasila Education is Problem Based Learning.

Problem Based Learning (PBL) departs from the active learning paradigm, in which the student becomes a learning center $[3,4]$. PBL as an instructional strategy has the main character that is using the problem as a trigger for learning a topic. Another characteristic of PBL is that the problem given is a problem that will be encountered by students in the daily life and requires a variety of knowledge in order to be able to analyze and solve the problem [5-7].

The Design of Pancasila Education designed by Meinarno and Saleh consists of three PBL sessions [2]. Each PBL session will consist of four meetings. The first meeting begins with the provision of a trigger that should be explored further in the student workgroup. Learning issues obtained as a result of exploration will be further explored by students by searching for various reference sources. The expected outcome of this meeting is a summary of the things that need to be known and learned from the problem. Teachers play a role in monitoring the discussion process and providing feedback that can lead students to achieve expected learning issues.

The second meeting contains the activities of delivering the results of the task and building the shared knowledge according to the definition of group problems respectively. At this second meeting, the teacher plays a role in providing oral feedback and clarification of students' understanding. The expected outcome of this meeting is that students build knowledge about the problems gained from different perspectives.

Furthermore, at the third meeting, students looked for some alternative solutions from the problems agreed by the group. This task is done jointly. Teachers play a role in monitoring discussion activities conducted by students. Expected output at the end of the session, students assess the useful performance behavior of their group of friends.

At the fourth meeting, the activities carried out were the exposure of the study results from each group. In this activity, teachers play a role in assessing the exposure and paper assignments based on several criteria. Teachers also play a role in monitoring the discussions and clarifying the results of the students' study.

The course of Pancasila Education for one semester will discuss three triggers. Each trigger will be addressed in four sessions. Include the session for formative and summative evaluation, then the whole meeting in one semester will be held in 12-14 sessions.

In the implementation of this Pancasila Education design, there are things that need to be further developed from the use of PBL in learning. The thing that needs to be developed is the 
learning assessment model that can be used to measure the learning objectives in Pancasila Education in universities.

Assessment is a general term that includes a set of procedures used to obtain information relating to the effort undertaken by the teacher to determine to what extent the learning objectives have been achieved [8]. Also, the assessment is also done by the teacher to be able to recognize the individual achievement of the students. Assessment and measurement terms are often considered to have the same meaning, although the assessment places more emphasis on authentic or performance-based measurements. Meanwhile, evaluation is a process by which teachers use information obtained from various sources to derive value judgment conclusions. Assessments may be based on data collected from measurements, but can also be found on various other data, such as questionnaires, direct observation, written or oral performance ratings, or interviews [8].

Assessment has many goals, one of which is to monitor the ongoing education program. Also, the evaluation also aims to determine whether an educational program has a positive impact is expected [9]. There are several forms of assessment used in educational settings ranging from standardized (e.g., National Examination), to non-standardized (for example, observations).

Brookhart states that doing an assessment of higher order thinking is necessary, but it is not an easy task. Therefore, assessment needs to be done to assess some ability or skill [10]. In learning using PBL, assessment is done to determine the level of knowledge relevant to the problem, competency in applying the knowledge they have to understand the problem, and problem-solving skills. Moreover, the assessment is also done to determine the skills in implementing the solution to the problem, the capacity to lead and facilitate collaboration, and the ability to self-directed learning [11].

In the design of Pancasila Education design, there are need to do different assessments. The needs have to be done because Pancasila and its values do not become learning materials, but become things that will be developed in the students. Therefore, the assessment undertaken not only measures and assesses the cognitive aspects of teaching materials, but also measures and assesses the affective and psychomotor aspects. This assessment will integrate the achievement indicators of learning objectives [12].

The use of assessments to measure various aspects will further measure learning outcomes, as emphasized by McKeachie \& Svinicki [5]. They also stated that learning is more important than just getting grades. Learning outcomes also include experience in the learning process and feedback obtained. Assessment on various aspects can also reduce student anxiety that may be more prominent in non-cognitive aspects, such as affective and psychomotor.

The form of assessment used to measure and assess the learning using PBL is divided into two forms, namely product assessment and performance assessment. Product assessment includes portfolio, a sample of work, experience reflection, logs or journals, project reports, models or media products. While performance assessment includes the presentation of oral, actual demonstration, participation in activities and interviews. According to Hallinger \& Bridges [11], learning using PBL performs two types of assessment, namely Type 1 (instructor-structured and instructor-judged evaluation); and Type 2 (instructor-structured and student-judged evaluation). Evaluations using Type 1 focus on the processes that arise during teaching and learning activities, outcomes or performance that surround the task, and knowledge gained during the task or as a conclusion of the task. Evaluation using Type 2 focuses on the learning outcomes obtained by students.

The problem raised in this study is to make an assessment design about the design of Pancasila Education course. The purpose of this research is to construct the assessment design of Pancasila Education course. The benefit of this research is to apply the results or the design of this assessment in the Pancasila Education learning activities at higher education level in Indonesia.

\section{METHOD}

This study uses literature study to develop the design of learning assessment from Pancasila Education. The type of literature study used is to review the references on the assessment of learning outcomes, especially those using PBL learning methods. With the aim that the selected literature is in accordance with its usefulness for finding problem solving in measuring the PBL method [13]. Based on the results of the review, an assessment model was developed using types 1 and 2 developed by Hallinger \& Bridges [11].

Assessment tools that will be designed for assessing the product of learning are the reflection of experience, records from student's work (logs), assessment of effective performance in groups, and student reports. As for performance assessment, an assessment tool that will be designed is the oral presentation of the results of the study and alternative solutions.

Hallinger \& Bridges explains that in the Type 1 student assessment (instructor-structured and instructor-judged evaluation), the assessment is done to see the process of teaching and learning activities [11]. Operationally, the assessment focuses on student skills in performing various roles (leaders, facilitators, recorders and group members), including managing meetings efficiently and maintaining a neutral position during group discussions. Also, the assessment also focuses on group skills in identifying and resolving problems, including being able to clarify processes undertaken to review topics of conversation appropriate to the meeting agenda, focusing on meeting objectives; and the ability of group members to use appropriate knowledge in dealing with the issues they choose.

In Type 1 there is also a test of knowledge to see what students have learned about the problem and the extent to which students have mastered the specific knowledge domain relevant to the problem. Also, the test of knowledge also wants to measure the mastery of basic knowledge of students about the problem, and measure the ability of students in transferring learned knowledge into the problems encountered. 
The skills in self-directed learning can also be known through the ability of students to find the learning issues contained in the problem and the ability to find relevant learning resources. It can also measure students' skills in problem-solving and knowledge of problem areas.

In the Type 2 student assessment (instructor-structured and student-judged evaluation), assessments are conducted to measure student learning outcomes through reflection on their learning experiences.

The points emphasized in the student assessment in PBL are combined with the values that exist in Pancasila. The values of Pancasila that will be measured through this assessment are operationalized into examples of attitudes and skills. The values, or sila, in Pancasila are aligned with the competence of SNDIKTI (2016) MKWU Pendidikan Pancasila. In these values, several attitudinal and skill points can be adapted to learning using the PBL method. The description of these precepts will be explained in the section below.

The first value, which is the Ketuhanan yang Maha Esa, can be operationalized in the attitude aspect of appreciating cultural diversity, views, religion, and beliefs, as well as the original opinions or findings of others. While in skill aspect is related to the ability to conduct self-evaluation process to workgroup which is under its responsibility, and able to manage to learn independently.

The second value, which is Kemanusiaan yang Adil dan Beradab, can be operationalized in the attitude aspect of contribution to improving the quality of life of society, nation, religion, and civilization based on Pancasila. While in skill aspect related to the ability to study cases of application of science, technology, art by his field of expertise to produce prototypes, standard procedures, designs or artworks; and capable of documenting, storing, securing, and rediscovering data to ensure validity and prevention of plagiarism.

The third value, namely Persatuan Indonesia, can be operationalized in the attitude aspect of a role as a proud citizen and love of the country, has nationalism and responsibility to the state and nation. While in skill aspect related to the ability to arrange the results of his studies in the form of working papers, design specifications or art essays and upload them to the college page.

The fourth value, which is Kerakyatan yang dipimpin oleh Hikmat Kebijaksanaan dalam Permusyawaratan/Perwakilan, operationalized in the attitude aspect of showing the responsibility for the work in the field of his expertise independently. While in skill aspect related to the ability to respond to the achievement of group work and supervise and evaluate the completion of work assigned to workers who are under his responsibility (as group leader).

The fifth value, which is Keadilan Sosial bagi seluruh Rakyat Indonesia, can be operationalized in the attitude aspect of cooperative attitude and has social sensitivity and awareness to society and environment. While in skill aspect related to the ability to apply logical thinking, critical, innovative, quality, and measurable in doing specific jobs in the field of expertise.

\section{RESULT}

The result of this research is the assessment model for assessing Pancasila Education. The output from this model is the assessment product that will be used in the implementation of Pancasila Education lesson using PBL. The type of assessment used is Type 1 (instructor-structured and instructor-judged evaluation), and Type 2 (instructorstructured and student-judged evaluation). Assessment products fall into two aspects, namely assessment forms and assessment rubrics.

Assessment forms comprise a discussion rating form, an oral presentation appraisal form, an assessment form of effective learning behavior in a group and a paper assessment form. The assessment rubric is also made so that the assessment can be standard for each teacher or student who assesses. The rating rubric is made according to the type of form used, plus the rating rub for the knowledge test.

Assessments corresponding to both types are carried out from the first to fourth of each of the learning sessions. At the first meeting, the teacher can conduct an assessment using a discussion rating form to measure the process of discussion that occurred. There are several measurable aspects of student skills in performing various roles in the group; respect for the diversity of views, opinions or original findings of others, the skills to recognize problems; active listening ability; the act of helping other members to understand the discussion; and putting opinions or feelings constructively.

In the first meeting, students also conduct self-evaluation of working groups under their responsibility. Also, it also uses appropriate knowledge in dealing with issues that have been formulated together and able to manage to learn independently. This self-evaluation is done through reflective writing containing what has been learned, how students will use their knowledge and skills learned in the future

At the second meeting, students took turns presenting the results of the study of the learning resources on the problem and building shared knowledge according to the definition of their respective group problems. Teachers can assess the insights of knowledge students have about the problem, how to appreciate the diversity of views, opinions or original findings of others. Also, it can also be assessed how far the students use appropriate knowledge with the issues formulated together in groups, and whether the student shows responsibility for the work in the field that has been assigned to him independently. Other things that can be assessed are the ability to record, store, secure, and rediscover data to ensure validity and prevent plagiarism; as well as the ability to prepare the results of his studies in the form of working papers.

At the end of the second meeting, all students received a form of assessment of effective learning behavior in the group. They will assess each other about the behavior of their group's learning in group discussion activities. The behavior assessed will be categorized into four groups. The first group is 
communication (clarity in explaining, active listening ability, acts of helping other members to understand the material). The second group is respect (show support for group members, put opinions or feelings constructively, and invite group members to be actively involved in discussions). The third group is openness (able to express a desire to learn the material, be able to ask for feedback on themselves, try new ways of doing things). The fourth group is cooperation (want to work together to develop group work plans, share responsibilities, and conduct monitoring and evaluation of the learning process that has been lived, has a social sensitivity and awareness of the group itself and the classroom environment).

At the third meeting, students looked for some alternative solutions to the problems that the group agreed to. This task is done jointly. Teachers can assess the extent to which attitudes contributed to the students in improving the quality of life in society, nation, religion, and civilization based on Pancasila. Also, it can also be assessed about the attitude in the role of citizens who are proud and love the country, has nationalism and responsibility to the state and nation. Meanwhile, the lecturer can also assess the students' ability to examine cases of application of science, technology, art by their field of expertise to produce prototypes, standard procedures, designs or artwork. Other skillful aspects of skill can be arranged in the form of working papers, design specifications or art essays and upload them to the college page. At the end of the third meeting, the students again assessed the behavior of their group's friends in the assessment of effective learning behaviors in groups.

Finally, at the fourth meeting, students presented the results of the study and some of the solutions to the problems that have been formulated together. In this activity, teachers can use oral presentation forms to assess some things. The assessed is the ability of students in assessing the case of application of science, technology, art by the field of expertise to produce prototypes, standard procedures, design or artwork. It also assesses the ability to apply logical, critical, innovative, quality, and measurable thinking in doing specific work in the area of expertise. More detailed assessments include how the systematics of presentation presentations; the timing of the presentation by the given time allocation; proper use of the Indonesian language; attitude in exposure; clarity in presentation; and ability to respond to inquiries and feedback. From other aspects of skills that can be assessed is the ability to be responsible for the achievement of group work and to supervise and evaluate the completion of work assigned to workers who are under his responsibility (as group leader).

The teacher will also assess the group paper that becomes the reference in the presentation. Assessment of the group paper or article is conducted through an assessment of the students' ability to examine cases of application of science, technology, art by their area of expertise to produce prototypes, standard procedures, designs or artwork. It also assesses the ability to apply logical, critical, innovative, quality, and measurable thinking in doing specific work in the area of expertise; and attitudes that contribute to students in improving the quality of life of society, nation, religion, and civilization based on Pancasila. Another thing that can be assessed is the ability to arrange the results of his studies in the form of working papers, design specifications or art essays and upload them in college pages; as well as the ability to record, store, secure, and rediscover data to ensure validity and prevent plagiarism.

Papers also get additional value when the group uses reference material for national or international journal articles. In the initial design of Pancasila Education [2] the use of referrals in the form of journal articles aims to build a scientific way of thinking for students who have just entered the college level.

Assessment forms are designed to measure limited performance tasks and broad performance tasks [14]. Performance tasks are limited in the form of structured essay duties in the form of performance, such as summarizing the reading or comparing a chart of the population of a country. While on a broad performance task, students are required to perform performance comprehensively, such as collecting and analyzing data.

Assessments to test students' knowledge are conducted through written tests. In a written test will be given some questions that aim to see the level of mastery of student knowledge about a problem. Hallinger \& Bridges also explained that the test of knowledge measures what students learn about problems and the extent to which students have mastered the specific knowledge domain relevant to the problem [11]. Also, the test of knowledge also wants to measure the mastery of basic knowledge of students about the problem, and measure the ability of students in transferring learned knowledge into the problems encountered.

The purpose of providing this written exam is to assess whether misunderstandings or misconceptions about basic concepts exist. Given this goal, the provision of a written exam may be an addition to an assessment that has been focused on product and performance. The exam questions are based on Bloom's cognitive domain taxonomy at analysis level (C4) and evaluation (C5). Based on these levels, the suitable type of questioning is essay questions, which can measure how far the students have the knowledge and the ability to analyze and apply the knowledge (concepts and principles) to the critical context.

The assessment rubric is based on the criteria in the assessment form. Valuation is tailored to the completeness of the requested criteria. Value scoring in the form can be adjusted to Likert-type scale or follow the benchmark assessment in every university.

\section{Discussion}

The goal of this study is to construct an assessment model for Pancasila Education course in higher education. This assessment model was based on the teaching design of Pancasila Education course proposed by Meinarno and Saleh in previous study [2]. The design use problem-based learning as learning method. This is inline with the learning goal, which 
is develop analytical thinking in students, so that they can master the knowledge needed to understand the problem. This teaching design can make undergraduate students become more active in building their knowledge, thus following the expected competencies [2].

Assessment models designed to measure learning outcomes Pancasila education can better measure learning outcomes as it measures various aspects, i.e. cognitive, affective and psychomotor. This is in line with that delivered by McKeachie \& Svinicki [5], which emphasizes that learning is important rather than value. The experience gained from the learning activities undertaken is part of learning. Similarly, assessment has benefits in helping to provide feedback to students about the process and results of their business. McKeachie \& Svinicki also stressed that by assessing the various aspects can reduce the anxiety of students who are cognitively less prominent, but have potential in affective or psychomotor aspects [5].

Assessment model that resulted from this research is assessment form from discussion, assessment to student presentation and design from formative and summative test. The type of assessment used is type 1 (instructor-structure and instructor-judged evaluation), and type 2 (instructor-structured and student-judged evaluation), developed by Hallinger \& Bridges [11]. With this type of assessment, the assessment model will be able to measure the learning outcomes of Pancasila Education using the PBL method. This is in line with Permenristekdikti No.44 of 2015 on the need to assess the performance of students, which is not only done by lecturers, but also by students themselves. The involvement of students to assess themselves will be useful in providing feedback on the extent of their mastery of lecture materials.

As mentioned before, Pancasila Education as one of the university compulsory course has a strategic position for character development. Therefore teaching and learning activities in Pancasila Education must be able to implement Pancasila values. Implementation of these values manifested in aspects of attitude and skills that need to be developed and mastered by students. The Pancasila Education Learning Plan proposed in our previous study combines an active learning approach that focuses on students, taking into account the cognitive developmental stages of students who have achieved post-formal thought stage, and the embodiment of Pancasila values in teaching and learning activities of Pancasila Education [2].

This assessment model is in line with 21 st century learning principles proposed by Brunige $[15,16]$, which consists of four principles, namely collaboration, critical thinking, creativity, and communication. The four principles underpin the process of student learning. In the principle of collaboration, students must work together with other students and with their lecturers, to construct and deepen their knowledge. Furthermore, highorder thinking skills, especially critical thinking, possessed by students must also be stimulated and enhanced. It aims to make the students develop into a thinker who has sensitivity to the problems that occur, and has a good comprehension about the theory and a broad insight in finding strategies for solving the problem. Student creativity can also be developed through activities that encourage variety of thinking skills and elaboration of ideas, such as brainstorming and group discussions. Finally, the principle of communication also underlies the discussion activities undertaken. Students learn how to communicate their ideas effectively and using several communication techniques in order to make other student understand their ideas. Through collaborative learning activities, the students' ability to communicate spoken and written will be develop.

In line with PBL learning methods, assessment in higher education needs to involve students actively in the assessment programs conducted by lecturers. Active student involvement can be an assessment of attitudes and participation in lectures, assessment of completion of tasks in lectures, and assessment of learning outcomes. This is consistent with those referred to by Permenristekdikti no. 44/2015.

In relation to the construction of knowledge formed by the students, this assessment model will be able to measure the mastery of Pancasila material because it integrates what they have learned theoretically-conceptually with the conditions that occur in the field. This is also in accordance with what was proposed by Ehrlich [17], students' mastery of Pancasila material will be more visible when they can integrate what they have learned regarding theoretical concepts with real conditions in society. Integration with Pancasila values, in the form of attitude and skills, also helps students to apply what they have learned before in the concrete context.

Assessment products fall into two aspects, namely assessment forms and assessment rubrics. Assessment forms are made to measure student performance tasks, whether it is limited or extensive. While the rubrics assessment will assist the lecturer to determine the criteria and level of performance of the students. This rubric can assist the lecturer in conducting the assessment and thus yielding the appropriate grade based on students' performance.

In the implementation of teaching and learning activities, the operational translation of Pancasila values can help teachers and students to internalize these values. Also, teachers and students can also measure achievement of learning outcomes objectively. Assessment forms and rubrics can be used as portfolios to see the progress students have made throughout their teaching and learning activities. With this assessment model, it can be said that all class activities undertaken are based on Pancasila.

\section{CONCLUSION}

This assessment model was created to implement in the design of Pancasila Education lessons at universities in Indonesia. This assessment model integrates the types of assessment used in learning with PBL and Pancasila values.

\section{REFERENCES}

[1] Buku Ajar Mata Kuliah Wajib Umum Pendidikan Pancasila. "Direktorat Jenderal Pembelajaran dan Kemahasiswaan Kementerian Riset, Teknologi, dan Pendidikan Tinggi Republik Indonesia”. 2016.

[2] Meinarno, E.A., Saleh, A.Y. "Learn from Problems: Ideas for Pancasila Education Course Design. Proceeding in The 3rd International Conference of Teacher Training and Education". Advances in Social 
Science, Education and Humanities Research (ASSEHR), volume 158. Atlantis Press. 2017

[3] Oktarina, P. S. Implementasi metode problem-based learning (PBL) untuk optimalisasi student-centered learning (SCL) di perguruan tinggi. Jurnal Penjaminan Mutu, 3(1), 76-86. 2017.

[4] Hartati, S., \& Lucky, N. Analisa penerapan PBL pada mata kuliah PPKN ditinjau dari ranah kognitif. Jurnal Keperawatan Abdurrab, 1(1), 19-26. 2017.

[5] McKeachie, W., \& Svinicki, M. McKeachie's teaching tips. Cengage Learning. 2013.

[6] Muhibbin, A., \& Sumardjoko, B. Model pembelajaran Pendidikan Kewarganegaraan berbasis isu-isu kontroversial di media massa untuk meningkatkan sikap demokrasi mahasiswa dan implikasinya bagi masyarakat madani. Jurnal Pendidikan Ilmu Sosial, 26(1), 1-10. 2016.

[7] Sukaptiyah, S. Peningkatan hasil belajar PKN melalui model problem based learning pada siswa kelas VI SD Negeri 1 Mongkrong, Wonosegoro. Scholaria: Jurnal Pendidikan dan Kebudayaan, 5(1), 114121. 2015.

[8] Burden, P.R., Byrd, D.M. Methods for Effective Teaching: Meeting the Needs of All Students 5th edition. Boston: Allyn \& Bacon, Inc. 2010

[9] Merrell, K. W., Ervin, R. A \& Gimpel, G. A. School psychology for the 21th century: Foundations \& practices. New York: The Guilford Press. 2011.
[10] Brookhart, S. M. How to assess higher-order thinking skills in your classroom. ASCD. 2010.

[11] Hallinger, P., Bridges, E.M. A Problem-based Approach for Management Education: Preparing Managers for Action. Dordrecht: Springer, Inc. 2007.

[12] Haris, H. Revitalisasi dan reinterpretasi pendidikan Pancasila: Ikhtiar strategis menuju pembangunan karakter bangsa. Penyunting: Dasim Budimansyah dan Prayoga Bestari. Dalam Aktualisasi nilai-nilai Pancasila dalam membangun karakter warga Negara. Widya Aksara Pres dan Laboratorium PKn UPI. Bandung. 2011.

[13] Kartodirdjo, S. Metode penggunaan bahan dokumen. Dalam Metodemetode penelitian masyarakat. Edisi ketiga. Penyunting Koentjaraningrat. PT Gramedia Pustaka Utama. Jakarta. 1979.

[14] Miller, M.D., Linn, R.L., Grunlund, N.E. Measurement and Assessment in Teaching 10th edition. New Jersey. Pearson Education, Inc. 2009.

[15] Brunige, M. 21st Century Teaching and Learning. NSW Department of Education. http://www.deac.nsw.gov.au/about-us/key-people/secretarysupdate. 21 st-century-teaching-learning. 2015.

[16] Marhaeni, AAIN., Santyasa, IW., \& Artini, LP. Pembelajaran di perguruan tinggi. Dalam Bahan Ajar Pekerti: Pelatihan Keterampilan Dasar Teknik Instruksional. Rajawali Pers. Jakarta. 2017.

[17] Ehrlich, T. Civic Education: Lessons learned. PS: Political Science and Politics, 32(2), 245-250. 1999. 